\title{
Who is Going to Build the Wall? A Building Trades Crisis in the U.S.A.
}

\author{
Ian Toppin* \\ Atlanta Technical College, Georgia 30310, USA
}

Received: 06.11.2017; Accepted: 31.01.2018; Published: 26.04.2018

\begin{abstract}
The context of this study was to examine factors contributing to significant workforce shortages in building trades in the United States. As it is, recruitment of qualified skilled trades workers is becoming increasingly difficult due to lack of a pipeline of prospective workers, and training programs.

The study assumed a theoretical inquiry approach in order to address the following three main questions: 1) What is the scope of the workforce shortage in skilled and building trades in the US? 2) What factors are recognized as contributors to the building trades workforce shortage in the US? And, 3) What strategies can be implemented to reverse building trades workforce shortages in the US?

Findings affirmed that the scope of workforce shortages in skilled and building (construction) trades in the US is very broad and the impact is rather deep. Factors contributing to the shortage include: declines in high school technical education programs, which have been replaced by career academies; misconception that higher education always equal higher income, but the untold story is higher debt associated with pursuing higher education; and stricter immigration laws, which are forcing potential workers out of the US.

The study concluded that in order to reverse currently declining workforce trends the following six strategies should be implemented: 1) Make it a national priority, thereby appropriating adequate resources to the effort. 2) Increase the number or women and African Americans in building trades. 3) Expand apprenticeship programs. An expansion of both government and corporate incentives are needed to stimulate an increase in apprenticeships. 4) Reintroduce building and skilled trades programs in secondary and postsecondary schools. Growth in the number of Career Academies, and participation in them has been encouraging, yet there are not enough of them to meet the need. 5) Re-examine guest-worker programs, which are currently cumbersome for employers to
\end{abstract}

\footnotetext{
${ }^{*}$ Corresponding author: itoppin@atlantatech.edu
}

ISSN: 2197-8646

http://www.ijrvet.net 
participate in, and do not allow for anywhere close to the number of workers needed to meet workforce needs. 6) Change marketing of building trades from menial to meaningful. Many young people simply do not know that they can make a comfortable living from a career in skilled trades. They have been taught that at least a bachelor's degree is needed in order to have a successful career. This narrative has to be revised in order to create a pipeline of prospective skilled trades employees for the future.

Keywords: VET, Vocational Education and Training, Building, Career, Technical Vocational Education, Construction, Skilled Trades, Workforce Education

\section{Introduction}

During the 2016 election campaign in the U.S., there were resurgences of comments and controversies from notable politicians and their supporters about building a wall across the entire southern border between the United States and Mexico. Reasons given for desiring to once and for all separate the U.S. from its southern neighbor, were to stem the flow of illegal immigration, reduce the volume of illegal drugs coming into the U.S. from Mexico and South America, and reduce the threat of terrorism by closing a porous border. However, a major question that needed to be asked in this debate was, where will the workforce to build the wall come from?

While one of the strategies for addressing the building trades workforce shortage in the U.S. must include recruitment from among all demographic groups, recent estimates from the Bureau of Labor Statistics (2016) indicate that $28.9 \%$ of the construction workforce are Hispanic or Latino. These groups are also among those most often targeted and deported for working in the U.S. without legal documentation. This situation heightens the possibility that there will be fewer workers available to work on constructing the border wall, or any other building projects, thereby exacerbating the workforce crisis in the construction industry in the U.S.

In the past, early efforts to steer young people toward skilled trades use to begin in middle $\left(5^{\text {th }}\right.$ or $6^{\text {th }}$ grade to $8^{\text {th }}$ grade) and high school $\left(9^{\text {th }}\right.$ to $12^{\text {th }}$ grade) in the US. Students encountered formal skilled trades training through vocational education (industrial arts) programs that were commonly referred to as "shop" programs. By the 1990s most of these programs were eliminated and replaced by Career Academies. This meant that Middle Schoolers began encountering formal skilled trades training at a much later stage in their academic journey, if at all. Kemple and Snipes (2000) provided the following description of Career Academies:

Career academies attempt to create more supportive and personalized learning environments through a school-within-a-school structure. Their curricula combine academic and occupation-related course requirements that aim both to promote applied learning and to satisfy college entrance requirements. Academies establish partnerships with local employers to build sequences of career awareness and work-based learning opportunities for their students ( $p$. ES-1). 
Career academies are generally characterized by three distinct features: Firstly, they are organized in cohorts of students (learning communities) who matriculate together for three to four years to provide a more supportive environment. Secondly, they combine academic and career and technical (vocational) curricula. Thirdly, they partner with local businesses and employers to provide career awareness and work-based opportunities so that students can acquire practical experience working in their proposed career field.

While career academies have proven to be highly successful in increasing engagement and performance, and reducing drop-out rates among students who participate in them, increases in enrollment numbers are needed before there can be sustained optimism, particularly about the future of building trades workforce in the U.S. The National Career Academy Coalition (2017) estimates that there are approximately 7,000 career academies in operation serving about one million students.

\subsection{Purpose of Study}

The purpose of this study is mainly to examine issues resulting in the current building trades workforce shortage in the U.S. and strategies that may be considered for reversing the shortage.

\subsection{Research Questions}

Literature review was based on the need to address the following questions:

1. What is the scope of the workforce shortage in skilled and building trades industries in the U.S.?

2. What factors are being recognized as contributors to the building trades workforce shortage in the U.S.?

3. What strategies can be implemented to reverse building trades workforce shortages in the U.S.?

\section{Scope of the Workforce Shortage in Skilled and Building Trades}

Nielsen (2016) stated that the term "skilled trades" includes various jobs that require training and contribute to the construction industry masons, bricklayers, electricians, plumbers, painters, carpenters, roofers, and heating and cooling (HVAC) workers. The terms "skilled trades" and "building trades" are often used interchangeably.

To emphasize the veracity of the growing workforce shortage in building trades, RenzeRhodes (2016), reported estimates from the Manufacturing Institute, which is an affiliate of the National Association of Manufacturers, and which reports that today's average age of a tradesperson is 56, and currently in the U.S. there are 600,000 skilled jobs, but by 2020, there will be a need for 10 million new skilled workers. Assuming this forecast holds true, the demand for skilled workers will grow significantly in the near 
future. Additionally, Wright (2013) noted that skilled trades have far fewer 65-and-older workers than the total labor force $(1.9 \%$ to $4.8 \%)$, which is a clear sign that skills trades jobs, being typically more physically demanding than other jobs, prevent workers from delaying retirement because they need the money or because they simply enjoy working. The fact is, many skilled trades workers come to a hard stop in their careers due to the physical demands of the job. Schwartz (2015) observed that for six consecutive years, skilled trade vacancies were the hardest to fill in the U.S., and for four consecutive years were the hardest to fill globally.

Signs of a crisis in the construction workforce was evident before the 2007 recession started. Gibbs (2005) echoed this sentiment by stating that America is facing a skilled labor shortage in the construction industry. However, Elejalde-Ruiz (2016) wrote that the construction workforce, which thinned out dramatically as work dried up during the economic downturn, is only three-quarters what it was pre-recession. Beyer (2017) quoted an economist for the National Association of Homebuilders (NAHB), who stated that the share of builders reporting either some or serious worker shortages has skyrocketed from 21 percent in 2012, to 46 percent in 2014, 52 percent in 2015, and 56 percent in 2016. These numbers obviously give reason for concern in light of the economic upturn in the Stock Market, which usually precipitates a boom in new construction.

Schwatka, Butler, and Rosecrance (2012) predicted that the number of jobs in the construction industry will continue to grow by $19 \%$ from 2008 to 2018 , compared with a projected $11 \%$ for all other industries combined. These authors also projected that growth of the construction industry will be hindered in the future by a shortage of skilled workers. Thus, keeping skilled workers employed in the industry is a high priority in the U.S.

Based on these findings, it seems evident that the scope of workforce shortages in skilled and building (construction) trades is very broad and the impact is rather deep.

\section{Factors Recognized as Contributors to the Workforce Shortage}

There may be a number of contributing factors to the building trades workforce shortage; However, the following three main contributors will be presented: 1) Decline in high school Technical Education Programs; 2) Misconception that higher education always equals higher income; and 3) Stricter immigration laws.

\section{Decline in high school technical education programs}

Krupnick (2017) reported that many fields are facing worker shortages because so much effort has been put into encouraging high school graduates to go to college for academic degrees rather than for training in industrial and other trades. Drew-Thompson (2014) postulated that the shortage in skilled trades and construction workforce began with the steady stripping away of technical education programs from public schools in the way our society, namely parents and educators, perceive how career paths are best determined.

For the past two decades there has been persistent declines in the number of technical 
education programs offered in high schools. As mentioned earlier, many of these programs are now offered through Career Academies, but many high schools do not have, nor are they associated with, a Career Academy. Hudson (2013) wrote in a National Center for Education Statics (NCES) report that the average number of secondary/ high school courses taken in career and technical education declined from approximately 4.2 credits in 1990 to 3.6 credits in 2009, while the average number of credits earned in other subject areas increased.

Traditionally, students who developed an interest in career and technical education (CTE) fields such as building and construction trades went to work immediately following high school. However, Oymak (2017) found that 74\% of ninth graders in 2009 expected their main activity in 2013 to be postsecondary education. Only $19 \%$ expected their main activity to be work. Oymak's report also found that students' expectation for postsecondary education increased as family socioeconomic status (SES) increased. This information seems to confirm that there is a diminished view in society today when it comes to the value of traditional blue-collar jobs.

\section{Misconception that higher education always equals higher income}

Many students shy away from pursuing skilled trades careers because of the misconception that higher educational achievement always equals higher income levels. Carlson and McChesney (2015) found that the higher the educational achievement, the higher the associated average salary. However, Hamm (2016) noted that such studies often do not paint the whole picture. Hamm argued that there is not much of a drop-off in salaries between trade school graduates $(\$ 35,720)$ and those with a four-year degree $(\$ 46,900)$, when the fact that trade school only takes an average of two years to complete versus four, and in many cases more than four years for a bachelor's degree. It puts the trade school graduate ahead by approximately $\$ 71,440$. Additionally, Hamm found that some youth may shy away from skilled trades because of parental, school, and even peer stigma, which associates skilled trades with lack of an ability to succeed in traditional academic areas of study.

Weller (2017) reported results from a review of U.S. Census data, which showed the top eleven college programs with the highest unemployment rates. Table 1 ranks each program in order by unemployment rate. Notably, none of the programs are in the skilled trades:

There are also disparities between salary levels for those with bachelor's degrees depending on field of study. In other words, all bachelor's degrees are not the same in terms of salaries and job prospects. Furthermore, Bondar (2016) cautioned that while most colleges try to create strong job-placement programs, if you are majoring in a subject outside of science, technology, engineering, math (STEM), or business field, schools are less equipped to help you find a job after graduation. On the other hand, vocational (trade) schools pride themselves on having strong partnerships with industries their graduates work in. 
Table 1: Eleven college majors with the highest unemployment rates

\begin{tabular}{llc} 
No & Program (major) & Unemployment rate \\
\hline 1 & Composition \& rhetoric & $17.54 \%$ \\
2 & Environmental science & $11,79 \%$ \\
3 & Anthropology \& archaeology & $11.76 \%$ \\
4 & Drama \& theater arts & $11.42 \%$ \\
5 & Film, video, \& photographic arts & $11.24 \%$ \\
6 & Mass media & $10.92 \%$ \\
7 & Fine arts & $10.90 \%$ \\
8 & Ethnic \& civilization studies & $10.84 \%$ \\
9 & Intercultural \& international studies & $9.93 \%$ \\
10 & Communications technologies & $9.40 \%$ \\
11 & Biology & $8.76 \%$
\end{tabular}

Another prohibitive factor worth mentioning is huge loans students are usually stuck with for years after completing a bachelor's degree. While Anderson (2017) agreed that learning a skill, such as welding, auto mechanics, or construction can lead to a lucrative career, a college degree has many benefits too. Therefore, a summary of research seems to suggest that a combination of skilled trade proficiency along with postsecondary educational attainment may be the best educational preparedness.

\section{Stricter immigration laws}

Conrad (2016), attributed the main causes for the workforce shortage to: a slow-down (67\% decrease from 2006-2013) in immigration to the U.S. over the past decade, foreign workers who have not returned to the U.S. after the housing crisis, and increases in opportunities in Mexico, along with increases in immigration enforcement along the border, which prevents workers from returning. While these immigration-related factors may be contributors to the workforce shortage, immigration also happens to be the one factor that seems to garner more political and legislative banter than any other. Nevertheless, because workforce shortages are so severe, a fresh look at immigration is more than likely the only viable short and long-term solution to the problem.

Table 2 below, which was adapted from a U.S. Bureau of Labor Statistics (2016) report, shows how various groups are represented in the building and extraction trades in the U.S. It indicates that in every category, Hispanic and Latino workers comprise a major portion of the U.S. workforce in these occupations. This means that changes in immigration policies, which are expected to significantly impact Hispanic and Latino populations, will also impact the workforce in industries where many of them are employed. 


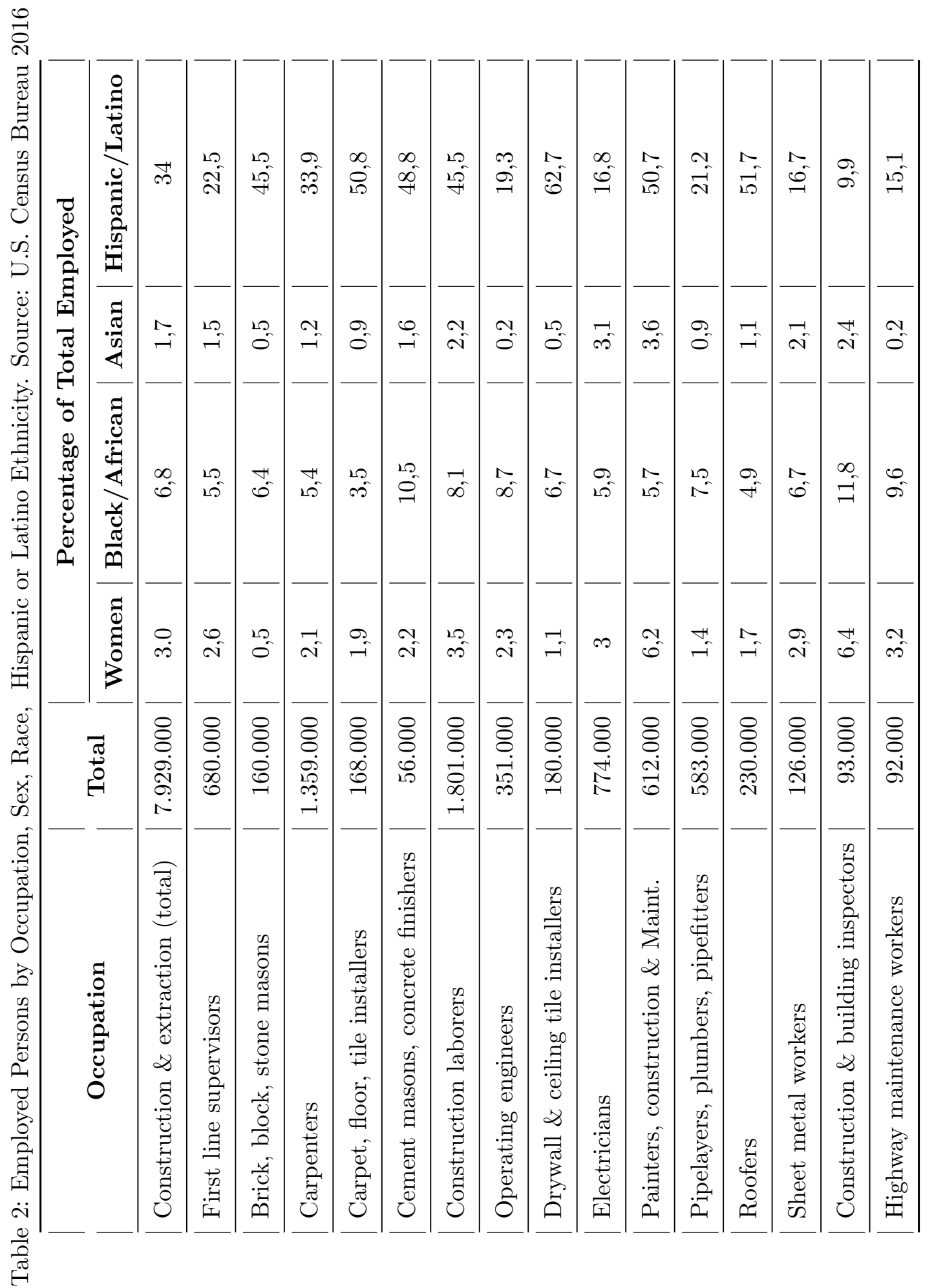




\title{
4 Strategies for Reversing Building Trades Workforce Shortages
}

\author{
Make it a national priority
}

Enactment of the Carl D. Perkins Bill, which provides federal funding for career and technical education (CTE) programs in the U.S. first occurred in 1984. Since then, there have been a couple of re-authorizations in 1998 and 2006. The Bill is currently up for another re-authorization and so far has gained enough by-partisan support to allow it to pass in the U.S. House of Representatives in 2017. Full re-authorization will once again affirm the U.S. government's strongest support for career and technical education. Following passage of the bill in the House, Nagurka (2017) stated that the work on Perkins will now be focused in the Senate, and he expressed hope that the Senate will make Perkins reauthorization a priority in the coming months. Staklis and Klein (2014) mentioned that the Carl D. Perkins Act sets a minimum allocation requirement that secondary and postsecondary CTE sub-grantees must achieve to receive federal financing. Such minimum requirements and the financial support grantees receive can go a long way in keeping CTE programs viable and in motivating educational institutions to offer them.

\section{Increase the Number of Women and African Americans in Building Trades Careers}

From a historical perspective, Wyatt and Hecker (2006) found that construction workers declined 31 percent as a proportion of total employment between 1910 and 2000, from 4.3 percent to 3.0 percent. Most of this decline was among carpenters. Carson (2011) stated that during the early history of the U.S., construction jobs were among the only employment Black men could get, and so a significant number of them worked in construction trades. However, the BLS chart above (table 2) provides substantial evidence of the current level of under-representation among women and African American men in building trades fields. Efforts to reverse the workforce shortage must include recruitment among these groups.

Additionally, reauthorization of the Workforce Investment Act (WIA), which was initially passed in 1998, or similar legislation, might be helpful. Best and Cohen (2013) indicated that WIA, which funds workforce education, career pathways programs, and other programs typically aimed at assisting low-income and other vulnerable groups, has not been reauthorized since its passage.

\section{Expansion of apprenticeships}

Finkel (2016) reiterated the fact that partnerships between community colleges and employers to create apprenticeships have been around for decades. These traditionally have covered fields like the building trades electrical, construction, and others as well as heavy manufacturing like the automobile industry. Continued support for these types of apprenticeships is sorely needed. Helper, Noonan, Nicholson and Langdon (2016), lauded the benefits of apprenticeships by asserting that the payoffs for workers is clear: 91 percent of apprentices find employment after completing their program, and their average starting wage is above $\$ 60,000$. As a result, the U.S. Department of Labor has 
invested $\$ 265$ million since 2015 to expand apprenticeships. Helper et al. also examined benefits to businesses which engage in apprenticeship programs. They reported that all of the firms they studied believe that apprenticeships improved their overall performance and provide a competitive advantage over other firms in three distinct areas: production, workforce (less turnover), and soft skills.

\section{Re-introduce building and skilled trades programs}

Apart from career academies, a number of skilled trades programs, which were once taught in secondary schools, if they are still offered are offered through dual enrollment with a community or Junior college. Students can receive sub-baccalaureate credentials (certificates, associates degrees) through these arrangements (Chen \& Schmidtke, 2017). The number of students who can be credentialed through the dual enrollment plan is directly impacted by the availability of institutions to engage in such arrangements. Hudson (2017) found that the number of occupational education institutions in the U.S. declined between 2000 and 2014. The following chart summarizes the decline:

Table 3: Postsecondary Institutions Offering Sub-Baccalaureate Occupational Education Programs

Type of Institution Institutions in 2000 Institutions in 2014 Percentage Change

\begin{tabular}{llll}
\hline Public & 35 & 29 & $17 \%$ \\
Private, non profit & 18 & 14 & $22 \%$
\end{tabular}

Occupational education is similar to career and technical education in that it is designed to prepare students for careers following their occupational training. A decline in institutions offering occupational education training undoubtedly impacts the supply of potential workers in building and skilled trades. Additionally, Roberts (2016) established that students who matriculate in sub-baccalaureate programs in occupational fields are less likely to persist to attaining a credential than those who matriculate in other fields. Therefore, institutions that offer occupational education curricula should also have strong student retention programs.

\section{Re-examine guest-worker programs}

Workforce shortages in building and construction trades in the U.S. have been so prolonged and increasingly intense that the problem appear unsolvable by a supply of workers who are either citizens or permanent residents of the U.S. Prospects seem more bleak now than they did in the past ten years. Political efforts to address the situation appear meager in light of the enormity of the problem. For example, Greenhouse (2013) reported that an immigration deal crafted in the U.S. Congress capped the number of guest construction workers admitted to the U.S. each year at 15,000, and in a bow to labor unions, bars admission for any higher-skilled workers like electricians, crane opera- 
tors or elevator repair technicians. Several major construction industry groups criticized the agreement, claiming that the number of visas allowed is too low.

Guest-worker programs allow workers from foreign countries to legally work in the U.S. particularly in high-demand areas where there is a shortage of U.S. workers. The type of visa issued is called an $\mathrm{H}-2 \mathrm{~B}$ visa, which is available to skilled or unskilled construction workers. In describing the requirements for employers to acquire guest workers, Slowey (2016) stated that the open position(s) must be of a one-time or seasonal nature, which excludes any work available year-round. Employers must show that there are no American workers able and willing to do the work, and they must cover all travel and visa expenses the guest worker might incur. These and other regulations make this option somewhat prohibitive for employers in the construction industry. Reform is needed to make guest worker programs friendlier and easier for employers to pursue with the appropriate government anti-abuse oversight.

\section{Change marketing from menial to meaningful}

A movement is needed to reeducate society, particularly parents and educators about what a good job looks like. Krupnick (2017) reported that the State of California is spending $\$ 6$ million on a campaign to revive the reputation of vocational education, and $\$ 200$ million to improve the delivery of it. The author noted that some view this as a "cultural rebuild." In reflecting on a message given by Senator Marco Rubio, RFlorida, during the 2016 presidential campaign, Krupnick echoed Rubio's statement that "welders make more money than philosophers."

Wright (2013) reported concerns that for two or three generations, the focus of education has been to go to college, get a degree and in doing so ensure a brighter future with more access to employment. The issue at hand is, the focus on academic instruction resulted in neglect of career education. Wright noted that in a two-year institution, costs are less, and the average student can finish with skills to gain immediate employment. Academic and career education do not have to be competing choices as they can complement each other. Most importantly, Wright concluded that skilled trades can provide a promising career path depending on a job seeker's skills and location. Somehow, this message has been lost, but it needs to be communicated again in order to reverse declining workforce shortages in skilled and building trades.

\section{Conclusion}

The desire to build a wall on the southern border between the U.S. and Mexico will likely bring greater attention to the building trades workforce shortage, which has grown to crisis levels. Since employers are finding it difficult to find workers for construction projects across the U.S. it should be expected that there will also be worker shortages to build the border wall. It should be expected that if the wall is to be built, a disproportionate number of workers on that project will reflect the way it is on projects across the country, namely, many of the workers will be immigrants. And, if immigrant workers are not available the wall will either take longer to build, or may not be built at all. 
There are no viable short-term options to addressing the skilled and building trades workforce shortage in the U.S. other than to through immigration and guest worker programs. Other options, such as promoting skilled trades in secondary and postsecondary institutions will not yield the number of workers needed to immediately address the shortage, and will take longer than can be afforded.

Admittedly, the social stigma associated with being a construction worker may not equal what it is in some other positions, which require traditional academic training, but that stigma needs to change because in many cases, skilled trades jobs pay as good, or better. The ability to earn a decent living by working in skilled trade should be communicated to young people who are often herded into academic disciplines, thinking that to be their only path to a successful life; only to find it difficult later due to high debt incurred trying to acquire the requisite academic training.

To reverse the workforce crisis, which is looking as if it will become worse in the years ahead, a multifaceted approach must be taken. It will require financial support from government and private stakeholders, favorable immigration legislation, reintroduction of skilled trades programs in secondary and postsecondary schools, increased participation in career academies, recruitment of workers from all demographic segments of the population, and rebranding the status of skilled and building trades professions in the U.S. as occupations that are as equally important and rewarding as any other.

\section{References}

Anderson, M. (2017). Skilled Trades Vs. College Degrees. Seattle PI. Retrieved September 15, 2017 from http://education.seattlepi.com/skilled-trades-vs-college-degrees1885.html

Best, J., \& Cohen, C. (2013). Reauthorization of the Workforce Investment Act (WIA): The Skills Act and Its Impact on Education. McREL International. Retrieved September 21, 2017 from http://files.eric.ed.gov/fulltext/ED557606.pdf

Beyer, S. (2017). America's Housing Construction Labor Shortage Continues. Forbes Magazine. Retrieved September 3, 2017 from https://www.forbes.com/sites/scott beyer/2017/04/29/americas-housing-construction-labor-shortage-continues/76b93bc $4706 \mathrm{c}$

Bondar, M. (2016). The Financial Case for Trade School Over College. US News. Retrieved January 15, 2018 from https://money.usnews.com/money / blogs/mymoney/articles/2016-04-12/the-financial-case-for-trade-school-over-college

Carlson, R., \& McChesney C. (2015). Income Sustainability through Educational Attainment. Journal of Educational and Training Studies, 3, 1, 108-115.

Carson, C. (2011). The Struggle for Freedom. A History of African Americans. Boston: Prentice Hall.

Chen, P., \& Schmidtke, C. (2017). Humanistic Elements in the Educational Practice at a United States Sub-Baccalaureate Technical College. International Journal for Research In Vocational Education and Training, 4(2), 117-145.

doi:10.13152/IJRVET.4.2.2 
Conrad, T. (2016). The Labor Shortage Thats Facing the Construction Industry. Retrieved September 25, 2017 from http://www.goliathcc.com/the-labor-shortage-thatsfacing-the-construction-industry/

Drew-Thompson, A. (2014). The Workforce Shortage Report. Constructor, the Magazine of the Associated General Contractors of America. Retrieved September 6, 2017 from http://www.constructormagazine.com/the-workforce-shortage-report/\#.WbA H5-1K201

Elejalde-Ruiz, A. (2016). Construction Contractors Warn of a Labor Shortage as Building Booms. Chicago Tribune. Retrieved August 28, 2017 from http://www.chi cagotribune.com/business

Finkel, E. (2016). Building a Strong Foundation: Apprenticeships Provide Earning, Learning Opportunities. Community College Journal, 86, 3, 12-16.

Gibbs, H. (2005). Building a Future for Future Builders. A Constructive Look at ACE Tech Charter School. Techniques: Connecting Education and Careers, 80, 1, 19-25.

Greenhouse, S. (2013). Construction Groups Criticize Limits in Guest Worker Deal. NY Times. Retrieved September 21, 2017 from http://www.nytimes.com/2013/04/05/ us/construction-groups-criticize-guest-worker-deal.html?mcubz $=0$

Hamm, T. (2016). Why You Should Consider Trade School Instead of College. The Simple Dollar. Retrieved September 15, 2017 from https://www.thesimpledollar.com/ why-you-should-consider-trade-school-instead-of-college/

Helper, S., Noonan, R., Nicholson, J., \& Langdon, D. (2016). The Benefits and Costs of Apprenticeships: A Business Perspective. U.S. Department of Commerce Report. Retrieved September 21, 2017 from http://files.eric.ed.gov/fulltext/ED572260.pdf

Hudson, L. (2013). Trends in CTE Coursetaking. Data Point, NCES 2014901. Retrieved September 11, 2017 from https://nces.ed.gov/pubs2014/2014901.pdf

Hudson, L. (2017). DATA POINT: Change in Number and Types of Postsecondary Institutions: 2000 to 2014. NCES 2017008. Retrieved September 21, 2017 from https://nces.ed.gov/pubs2017/2017008.pdf

Kemple, J., \& Snipes, J. (2000). Career Academies: Impacts on Students' Engagement and Performance in High School. Manpower Demonstration Research Corporation. Retrieved January 15, 2018 from https://www.mdrc.org/sites/default/files/Career Academies_Impacts_on_Students.pdf

Krupnick, M. (2017). After Decades of Pushing Bachelor's Degrees, U.S. Needs More Tradespeople. The Hechinger Report. Retrieved August 31, 2017 from http://hechi ngerreport.org/after-decades-of-pushing-bachelors-degrees-u-s-needs-more-tradespeo ple/

Nagurka, J. (2017). House Passes Perkins Reauthorization Bill. CTE Policy Watch Blog. Retrieved September 21, 2017 from http://ctepolicywatch.acteonline.org/perkins/

National Career Academy Coalition (2017). Career Academies Change Lives Every Day. Retrieved on January 15, 2018 from https://www.ncacinc.com/nsop/academies

Nielsen, D. (2016). Contractors Frustrated by Worker Shortage. Associated Press. Retrieved August 28, 2017 from http://www.washingtontimes.com/news/2016/oct/ $2 /$ contractors-frustrated-by-worker-shortage/ 
Oymak, C. (2017). The Education and Work Plans of Public High School Students. NECS 2017005. Retrieved September 11, 2017 from https://nces.ed.gov/pubs2017/ 2017005.pdf

Renze-Rhodes, L. (2016). Shortage of Workers Impacts Skilled Trades. Retrieved November 23, 2016 from https://www.angieslist.com/articles/shortage-workers-im pacts-skilled-trades.htm

Roberts, A. (2016). Persistence and Attainment among Postsecondary Subbaccalaureate Students. Data Point, NCES 2016083. Retrieved September 25, 2017 from http://files.eric.ed.gov/fulltext/ED567226.pdf

Schwartz, H. (2015). U.S. Employers Suffer Largest Talent Shortage in Skilled Trades. Retrieved September 15, 2017 from https://facilityexecutive.com/2015/05/u-s-empl oyers-suffer-largest-talent-shortage-in-skilled-trades/

Schwatka, N., Butler, L., \& Rosecrance, J. (2012). An Aging Workforce and Injury in the Construction Industry. Epidemiologic Reviews, 34, 1, 156-167.

Slowey, K. (2016). Truly No Better Option: H-2B Visas for Construction Workers Spark Industry Controversy. Construction Dive. Retrieved September 21, 2017 from http://www.constructiondive.com/news/truly-no-better-option-h-2b-visas-forconst ruction-workers-spark-industr/421224/

Staklis, S., \& Klein, S. (2014). Consortia Formation and Characteristics Under the Carl D. Perkins Career and Technical Education Act of 2006. U.S. Department of Education, Office of Career, Technical, and Adult Education. Retrieved September 21, 2017 from http://files.eric.ed.gov/fulltext/ED555227.pdf

U.S. Bureau of Labor Statistics (2016). Labor Force Statistics from the Current Population Survey. Retrieved from https://www.bls.gov/cps/cpsaat18.h tm

U.S. Bureau of Labor Statistics (2016). Labor Force Statistics from the Current Population Survey. Retrieved September 11, 2017 from https://www.bls.gov/cps/cpsaat 11.pdf

Weller, C. (2017). The 11 College Majors with the Highest Unemployment Rates. Business Insider. Retrieved October 11, 2017 from http://www.businessinsider.com/col lege-majors-producing-the-highest-unemployment-rates-2017-10

Wright, J. (2013). America's Skilled Trades Dilemma: Shortages Loom as Most-InDemand Group of Workers Ages. Retrieved November 23, 2016 from https://www.f orbes.com/sites/emsi/2013/03/07/americas-skilled-trades-dilemma-shortages-loom-a s-most-in-demand-group-of-workers-ages/8d1ca086397c

Wyatt, I., \& Hecker, D. (2006). Occupational Changes During the $20^{\text {th }}$ Century. Monthly Labor Review, March 2006, 35-57. Retrieved September 19, 2017 from https://www.b ls.gov/mlr/2006/03/art3full.pdf

\section{Biographical Notes}

Dr Ian Toppin is Dean of Industrial and Transportation Technologies at Atlanta Technical College in Atlanta, Georgia, United States. Dr. Toppin's research interests focus on workforce issues, educational technology, and faculty professional development. 